\title{
Selected determinants of the professional identity of dietitian in the context of legal regulations on the practice of dietitian in Poland and the European Union
}

\begin{abstract}
The subject of the article is the present status of the profession of dietitian in the Polish healthcare system, taking into account the analysis of the current legislation in force that defines the principles of employment of dietitians and the practice of the dietitian in Poland in the context of relevant provisions of the EU law, with emphasis on the position of dieticians in the health-care systems of selected European Union countries. The study advances the thesis that the current status of the profession of dietitian in Poland reflects its incomplete professionalization manifested in the lack of legal regulations on the principles of its practice that are applied in the case of other medical professions. A consequence of the present, comparatively low status of the profession of dietitian in Poland is, inter alia, the hindered availability of professional clinical dietetics counseling under public health insurance, as well as the practice of the profession as a business activity by individuals whose professional qualifications are not subject to verification by professional regulatory bodies. This produces a risk to patients, arising from the fact that interventions not verified by the EBM paradigm are nevertheless implemented as part of dietary counseling.
\end{abstract}

Keywords: dietitian, medical professions, regulated professions, professionalization, nutrition therapy.

DOI: $10.2478 /$ pjph-2018-0011

\section{INTRODUCTION}

The starting point for the analysis is the definition of a European dietitian formulated by the European Federation of the Associations of Dietitians (EFAD) in 2015 [1], according to which a dietitian is:

"A healthcare professional authorized/registered to prescribe and give advice on human nutrition, food, dietary modification/treatments and to counsel patients, their relatives or the general public directly in institutional, community and educational settings and other work places to improve health and treat disease."

The cited definition stresses the clinical dimension of dietetic practice and the dietitian's responsibilities related to the implementation of the goals of public health. This "dual" nature of the professional activity of dietitians, closely connected with medical sciences in both aspects, imposes definite requirements concerning education in dietetics, which should optimally be pursued in medical universities that offer clinical training and training in public health [For more see 2]. The aspect of dietitians' activity involving clinical counseling ("to counsel patients [...]"), also implies the need for interpersonal competencies which should be acquired in the education process conducted in a similar way as in the case of the other medical professions. This requirement can be optimally fulfilled in medical universities because they have an appropriate institutional and personnel base: departments of the humanities and professionals in medical humanities that conduct training in soft competencies, intended for the future healthcare personnel. EFAD [1] experts directly speak on the subject, stressing that the application of soft competencies in the field of dietetics is a requirement that results from the activities of dietitians aimed to produce behavior change:

"Practitioners of dietetics use their understanding of sociology and psychology together with interpersonal skills to support behavior change for better health in groups and individuals."

Dietetics as a parent discipline of the profession in question is defined by EFAD [1] as: "an interdisciplinary and applied subject including natural, clinical and social sciences."

An integral element of the scientific foundations of the discipline are, in turn, the achievements of clinical and social sciences. It is moreover emphasized that the optimum formula of dietetics is Evidence-Based Dietetics [3], therefore its constitutive feature in view of its clinical tasks ("to counsel patients [...]"[1]) is: to be based on the results of epidemiological and clinical research on the relationship between nutrition and health and the role of nutrition in medical treatment

\footnotetext{
${ }^{1}$ Department of Clinical Dietetics, Faculty of Health Sciences, Medical University of Lublin, Poland

${ }^{2}$ National Center for Dietetics, Institute of Food and Nutrition, Warsaw, Poland

${ }^{3}$ Clinical Nutrition Unit, Independent Public Clinical Hospital No. 4 in Lublin, Poland

${ }^{4}$ Adamina Partycka-Skrzypek Law Office, Lublin, Poland
} 
as well as to apply in practice, analogously to the assumptions of the Evidence-Based Medicine paradigm, only such nutritional interventions whose safety and efficacy have been proved in methodologically rigorous clinical studies.

\section{AIM}

The goal of the study is to present the current legal provisions regulating the functioning of the profession of dietician in the Polish health care system as compared with EU's selected legal provisions concerning regulated medical professions. The study has been prepared based on the analysis and synthesis of Polish and European legislation on the issues in question as well as on the basis of directives defining the scopes of dietician's activity in the institutional contexts in Poland.

\section{The current status and scope of responsibilities of the dieti- tian in the Polish healthcare system}

In Poland, a dietitian is a person who, under the Regulation of Minister of Health of 20 July 2011, has appropriate professional qualifications and experience [4]. However, the document in question does not specify these requirements more precisely. Nor does it specify the conditions for the provision of services offered by dietitians in the sense of tasks that they would perform as part of their professional responsibilities. The Health Minister's Regulation of 19 December 2014 amending the regulation on guaranteed services in sanatorium and health-resort treatment stipulates that the dietitian's task is to use "proper diet" but it does not fully specify who designs such a diet, prepares and serves it. The dietitian's task is also to conduct "health education and health promotion" [5]. The absence of consistent regulations defining the rules of employing dietitians (the Polish regulations in force concerning this issue are discussed below) cause both hospitals and outpatient treatment facilities to refuse to employ dietitians, what limits or prevents access to professional dietary counseling as part of the health care system in Poland. The result of the lack of regulations on employing dietitians is that in Poland the employment of a dietitian at a given position and assignment to him concrete responsibilities is mainly decided by the employer. It should be added that dietary counseling is not treated as a medical service refunded by the National Health Fund (NFZ). The lack of a central register of dietitians (other questions concerning the regulations of the profession of dietitian in Poland and EU are discussed below) results, in turn, in that it is not exactly known what percentage of dietetics graduates practice their profession, how many dietitians are employed in other sectors, and how many have gone abroad. The only

TABLE 1. Employment of dietitians as intermediate medical personnel in healthcare facilities in Poland.

\begin{tabular}{ccccccc}
\hline \hline Year & $\mathbf{2 0 0 5}$ & $\mathbf{2 0 1 0}$ & $\mathbf{2 0 1 2}$ & $\mathbf{2 0 1 4}$ & $\mathbf{2 0 1 5}$ & $\mathbf{2 0 1 6}$ \\
\hline Number of dietitians & 1665 & 1372 & 1192 & 1171 & 1067 & 559
\end{tabular}

register of dietitians is kept by the Center for Healthcare Information Systems. It contains data that show a drastic decline in the employment of dieticians in healthcare institutions (Table 1) $[6,7]$. In contrast, the number of dietitians with university degrees employed in healthcare facilities was 908 in 2014, and in 2015 - 961 [6].

The potential of dietetics in prevention, both primary and secondary, was noticed by the Supreme Audit Office (NIK) ex- perts who inspected the state of nutrition in hospitals in 2018 [8]. Following the inspection, a number of irregularities were found, inter alia deficiencies in basic mineral components in hospital food rations (calcium from 19\% to 63\%; iron from $27 \%$ to $52 \%$; magnesium from $14 \%$ to $43 \%$ ), deficiencies of three important vitamins (vitamin E from 18\% to $43 \%$, vitamin B1 from $18 \%$ to $49 \%$; vitamin $\mathrm{C}$ from $30 \%$ to $66 \%$ ) and excessive intake of vitamin A (from $114 \%$ to $259 \%$ ) [8] as well as an excessive salt content in meals, reaching $374 \%$ as compared to recommended norms [9]. The NIK's post-inspection conclusions stated that the dietitian should conduct the education of patients, assess the state of patients' nourishment and the quality of food, participate in preparing and planning diets [8]. It is not possible to implement these conclusions when dietitians are omitted as an integral part of medical personnel reserves in Poland. Dietitians should be part of the treatment team and they should, in cooperation with the teams of doctors and nurses, play the crucial part of liaison between the treatment personnel and patients in the field of nutrition. Their presence is indispensable in proposing special diets, in supervising and carrying out special forms of oral nutritional treatment appropriately as the clinical situations of patients require, as well as in educating patients in the aspects of health literacy that refer to nutrition.

\section{Legal aspects of access to dietary services in the Polish healthcare system}

The relatively low status of dietitians in the Polish healthcare system results in that dietary services at the sufficiently substantive level are not generally available to outpatients and inpatients [10]. Our thesis is that in order to provide complex nutritional care it is necessary to employ professional certified dietitians in healthcare facilities. The lack of appropriate professional competencies in the cases of persons providing medical services in the field of nutrition may produce hazards to patients' health and lives [11]. We will repeat in this context the thesis formulated in earlier publications of the Department of Clinical Dietetics that only the education of dietitians in a medical university which has an adequate clinical base and lays emphasis on the clinical aspects of professional training of dietitians, can fully prepare a future dietitian for work with patients in diverse clinical and institutional contexts [2].

The next part of the article analyzes legal provisions that regulate the rules of employing dietitians in the Polish healthcare system, as well as selected guidelines of medical societies on the participation of dietitians in the treatment team. The first to be analyzed is the Regulation of the Minister of Health from 8 February 2018, amending the regulation on detailed criteria for choosing tenders in proceedings to conclude contracts for the provision of medical services, which specifies the required qualifications of the medical personnel providing specific medical services in individual specialist clinics. The document stipulates that a dietitian should be employed for at least $50 \%$ of working hours in a metabolic diseases clinic and $25 \%$ of working hours in a diabetes clinic [12]. In turn, in the Health Minister's Regulation of 22 November 2013 on guaranteed hospital treatment services, as amended, the dietitian is classified as "the other personnel". In light of the Regulation, the dietitian should be employed at the diabetes and children's diabetes departments at least 0.5 of working time as a diet planner (see Part 1. Detailed conditions that should be met by guaranteed services providers in the area of hospi- 
talization and planned hospitalization) [13]. Next, in compliance with the recommendations of 2018 of the Polish Diabetes Association (PDA) on the management of diabetic patients, for every 15-20 diabetes beds for adults the treatment team should consist of 2-3 doctors, 2 nurses with experience in taking care of diabetic patients, a dietitian employed at least halftime, a psychologist, and a social worker [14]. In the case of children's wards the PDA recommends that a dietitian should be employed full time for every ten beds, and part-time $(50 \%$ of normal working hours) in the case of outpatient counseling for every 300 patients. In contrast, a dietitian should be employed half-time at a specialist diabetes department and in diabetes clinic, both for adults and children [14]. Observe that according to the PDA "all diabetic patients should be educated about the general rules of proper diet in diabetes by qualified persons (doctor, diabetes nurse, diabetes educator) using different methods and techniques (...)" [14]. In the light of this standpoint, nutritional education of diabetic patients would have to be conducted by all members of the treatment team. It is a controversial recommendation because the level of the nutritional knowledge of individual treatment team members is diversified, particularly regarding specialist dietary issues. As we can thus see, there are divergences between the stance of PDA and the legal provisions regulating the employment of dietitians in the healthcare system in Poland. What manifests itself here, apparently, is the lack of the coordinated influence of the opinion-making body representing the professional circles of dietitians.

The next stage of analysis will focus on the recommendations on screening the nutritional condition of hospitalized patients. By the decision of the Minister of Health, as of 1 January a screening assessment of the state of patients' nourishment in each hospital department except for accident and emergency departments and one-day treatment departments [15]. This regulation was retained in the consolidated text of the Minister of Health Regulation of 14 April 2016 on guaranteed hospital services, which maintained the obligation to make a screening assessment of the state of nourishment in all beneficiaries of services provided as a part of emergency hospitalization and planned hospitalization, except emergency departments, ophthalmology, otolaryngology, allergology, orthopedics and traumatology departments, as well as in cases when hospitalization lasts under three days [16]. The fulfillment of the foregoing directives does not always result in adequate nutritional management because in hospital departments there are not enough professionally educated dietitians who would implement nutrition care for undernourished patients or those at risk of undernourishment. It should be stressed that not all improperly nourished patients require enteral or parenteral nutrition. In most of them it is enough to modify oral diet and to introduce the supervision by a dietitian over the implementation of dietary recommendations by the hospital kitchen/catering firm. Following the properly conducted nutritional treatment during hospitalization, the patients' state of nourishment may change, that is why the assessment of the state of nourishment should be repeated. A specialist in dietetics should also be available to patients discharged from hospital with undernourishment symptoms. The patient at risk of undernourishment or undernourished, who cannot continue dietary management or nutritional treatment after hospitalization, will not fully return to community life and may, relatively soon, return to hospital in a worse condition, requiring rehospitalization for a longer period.

We will now focus on the Standards of Parenteral and Enteral Nutrition issued by the Polish Society for Parenteral, Enteral Nutrition and Metabolism, in the light of which, the dietitian should be a member of the nutritional treatment team that identifies and treats patients at risk of nourishment disorders $[17,18]$. Under the Minister of Health Regulation of 15 September 2011 amending the regulation on guaranteed hospital treatment services, the provider of hospitalization and planned hospitalization services and conducting nutritional treatment is obliged to formally appoint a team of such specialists [15]. With the growing awareness of medical personnel on illnessrelated undernourishment and the growing conviction of doctors and nurses that the role of the dietitian is important in this field, the number of such teams in Poland is increasing.

The duties of dietitians in the field of medical rehabilitation are defined in the Legal Notice of the Minister of Health of 30 January 2018 on the announcement of the consolidated text of the Health Minister's Regulation on guaranteed services for medical rehabilitation. The document points out health education as an element of rehabilitation process, emphasizing that patients should be provided with at least 2 dietary-nutritional consultations during the process of cardiac rehabilitation as part of comprehensive care after myocardial infarction, conducted in the stationary form or in a day-center or day ward. The personnel taking care of a patient covered by stationary cardiac rehabilitation should include a dietitian with a BA or MA in dietetics [19]. This is a provision which is not fully observed because there are outpatient metabolic diseases clinics that offer paid dietary services while some do not offer such services at all, and only in some of them dietary counseling offered during a consultation with a doctor is refunded (e.g. at the Metabolic Diseases Outpatient Clinic of the Institute of Food and Nutrition in Warsaw).

Another important problem from the standpoint of patients' safety is the lack of legal regulations in Poland defining the conditions for the practice of the profession of dietitian in private dietitian's offices. This is one of the consequences of the fact that the profession of dietitian has not yet acquired the status of regulated profession. At present, the issues connected with the setting up and operation of a dietitian's office are regulated by the Act of 2 July 2004 on the freedom of business activity and the Act of 19 November 1999. The Act on business activity does not grant the registration authority the right to verify whether the applicant for entry in the registry of entrepreneurs in the National Court Register has appropriate professional qualifications [20-22]. As a result, it happens that dietary counseling is practiced by persons without appropriate qualifications to assess and diagnose the patient's state of nourishment. The implementation of nutritional interventions not verified by the EBM paradigm and not adjusted to the standards of dietary management in specific clinical conditions, including e.g. obesity, what may result in the deterioration of the patient's health condition $[2,23]$.

Also at the level of primary health care, the regulations stipulated in the Act on primary health care do not provide for the use of professional, widely available dietary counseling and nutritional education as part of general practitioner's practice. The Act stipulates that the primary healthcare team consists of a doctor, nurse and a midwife [24]. Contrary to earlier announcements, there are no provisions that would include a di- 
etitian in the primary healthcare team [25]. Highly controversial to the professional circle of dietitians are the provisions in the Regulation of the Health Minister of 28 September 2016 on the scope of responsibilities of primary healthcare doctor, primary healthcare nurse, and primary healthcare midwife, which extend the range of duties of primary healthcare nurse and midwife to include nutritional education and dietary planning [26]. The level of professional responsibilities imposed on these professionals - specific to the professions of nurse and midwife - is, apparently, sufficiently high and it appears doubtful that representatives of these professions will be capable of broadening their knowledge with the data taught during the BA and MA programs in dietetics comprising a total of ca. 5000 hours of instruction.

In Poland there are no regulations concerning the rules of contracting medical services provided by dietitians by the National Health Fund [10].

To sum up this part of analysis, it should be said that the current regulations in force do not create conditions for the availability of professional dietary counseling to patients treated under the national health insurance. A condition for the complete inclusion of dietitians in the healthcare system should be to compile a register of practitioners of this medical profession [10]. This must be preceded by the introduction of the system for verification of the professional competencies of persons who use the professional title of "dietitian" e.g. through a state examination [2]. A favorable effect on the strengthening of the professional position of dietitians in the Polish healthcare system would be exerted by the completion of work on the draft law on some medical professions and the rules for obtaining the title of specialist in other disciplines that have applications in health care, which regulate the conditions for license to practice medical professions, including the profession of dietitian, the rules of practicing them, the duty of continuing education, the rules of professional accountability and of maintaining professional secrecy [2]. The fundamental goal of the proposed regulation of the dietitian's profession is to widely spread the use of professional dietitian's services and make such services available based on universal free access or partially paid access for those ill and healthy persons in whose cases prevention and treatment requires the implementation of dietary management [10]. Professionally organized dietary counseling would allow reduction of expenditure on health care. The treatment of patients with obesity and obesity-related diseases in Great Britain generates social services worth from 0.4 to 1.9 billion euro in five-year periods. It has been calculated that to one euro spent on dietary counseling there is a saving of from 14 to 63 euro over 5 years owing to the improvement of the patient's health, in the costs of health care and increased efficiency of the patient's work [27].

\section{The legal status of the profession of dietitian in Poland and in $\mathbf{E U}$}

Each European Union country itself decides the regulation of a profession. In the light of Directive 2005/36/EC 2005 of the European Parliament and of the Council of 7 September 2005 on the recognition of professional qualifications 'a regulated profession' is

"a professional activity or group of professional activities, access to which, the pursuit of which, or one of the modes of pursuit of which is subject, directly or indirectly, by virtue of legislative, regulatory or administrative provisions to the possession of specific professional qualifications; in particular, the use of a professional title limited by legislative, regulatory or administrative provisions to holders of a given professional qualification shall constitute a mode of pursuit [...]" [28].

In the light of the provisions of Community law, a characteristic feature of a regulated profession is that its practice in a given EU country depends on the conditions specified by the domestic law: a given profession may be treated as a regulated profession in one EU Member State but not in another $[29,30]$. This kind of discrepancy exists regarding the profession of dietitian, which has the legal status of a regulated profession in most European countries, inter alia in Great Britain, Germany, Italy or France, but not in Poland. This is an incomprehensible situation in the light of other legal provisions under which the dietitian is a medical profession in Poland. Broader arguments for this thesis have been presented in earlier publications [see 2]; at this point we will only refer to the relevant provisions of the Polish law regarding this issue. In the light of the Regulation of the Minister of National Education and Sports on the classification of occupations in vocational education, a dietitian is a medical profession subordinated to the Minister of Health [31]. Strong arguments for the thesis that a dietitian is a medical profesison are provided by the Act of 15 April 2011 on medical activity, which stipulates that a specific feature of a medical profession is that a person practicing such profession provides healthcare services, i.e. conducts "activities that serve to retain, save, restore or improve health as well as other medical activities resulting from the treatment process or from separate provisions regulating the rules of their performance" [32]. Article 3 of the Act emphasizes that "medical activity consists in the provision of health services" and it can also consist "in the performance of teaching and research tasks in connection with the provision of health services and health promotion [...]" [32]. The range of dietitian's professional competencies fulfils the statutory definition of medical activity and health services, which justifies treating the dietitian as a medical profession. Such postulates are strongly substantiated by the stance of the EFAD [33], in the light of which the profession of dietitian is an integral element of the group of "healthcare professions", which are characterized by the fact that they all: "have 'care' as their core business. Care can be defined as a sensitive, competent and [integral] response to someone's needs. [...]" [33]. We touch here upon the issues of the professionalization of the dietitian's occupation, consisting in its transformation into a profession. This process involves the emergence of professional regulatory bodies which decide the admission of new persons to the pursuit of the profession, then the development of the rules for acquiring professional qualifications, as well as obtaining professional autonomy based on social trust [33]. The foregoing EFAD document says that in a number of EU countries (inter alia Great Britain and Germany) there are professional regulatory bodies that represent the professional circle of dietitians; however, the process of professionalization of the dietitian's occupation has not been completed everywhere. Regrettably, one of such countries is Poland.

Postulates concerning changes in the legal status of the dietitian's profession in Poland and training for this profession 
A legal challenge in Poland, determining the full professionalization of the dietitian's profession as well as optimization of the quality of dietary medical services, is the enforcement of qualifications to practice the dietitian's profession in accordance with the rules defining the practice of other medical professions. The issue here is, inter alia, the certification of qualifications necessary for the pursuit of a given profession by a university degree obtained in Poland or a European Union Member State [for more on training dietitians see 2] and the entry in the register of persons qualified to practice a given medical profession [29]. The finalization of the work on the draft law on some medical professions, regulating the rules of access to the pursuit of medical professions, including the profession of dietitian, would enable the enforcement of other duties resting on practitioners of medical professions, including inter alia the duties of continuing education and maintenance of professional secrecy; it would also be possible to enforce professional accountability in cases of dietary management not compliant with medical guidelines, and detrimental to patients. Especially the last of the foregoing issues appears to be of urgent importance in the context of the increasing frequency of application by persons without professional training in dietetics of diverse dietary pseudo-therapies of unproven curative value, particularly in the management of obesity, which do not reduce the risk of metabolic complicacies but are only focused on making the patients slim, disregarding measures aimed at the long-term maintenance of the obtained results [23]. The entry in force in Poland of legal regulations following the example of solutions implemented in a number of EU countries on the regulation of the dietitian's profession (The Draft Law on some medical professions says that a dietitian is a regulated profession in $17 \mathrm{EU}$ countries) [see 28 on this issue] would require verification of professional competencies of persons using the professional title of dietitian, sometimes illegitimately, for example through a state examination for applicants for entry in the registry of dietitians licensed to practice their profession. It should be stressed that the full professionalization of dietitian's profession would significantly enhance the chances for employment of graduates in dietetics who graduated from universities in Poland because the holding of comparable professional qualifications would enable them to enter the European labor market [see 34]. It should be emphasized once again that in Poland anyone who registers business activity and opens a private dietitian's office can provide dietary services with the full sanction of the law. This is one of the consequences of the fact that Poland has not introduced the system of verifying professional competencies of persons using the title "dietitian" and that the quality of services provided by dietitians is not controlled, nor is there any complete register of dietitians.

Article 3 of Directive 2005/36/EC 2005, regarding the definition of a regulated profession, emphasizes the issue of "possession of specific professional qualifications" as an integral element of the legal concept of 'regulated profession' [28]. At present in Poland, in the light of the guidelines of the Polish Association of Dietitians it is possible to obtain the professional title "dietitian" after doing a professional university degree in dietetics: BA and MA; the Polish Association of Dietitians emphasizes that the BA (first cycle) program lasts not less than 6 terms and the MA (second cycle) program not less than 4 terms [35]. In the earlier publication, M. Skrzypek and K. Goral [2] presented a broader analysis of the issue, suggesting that the dietitian optimally prepared to pursue clinical practice in different institutional contexts should possess knowledge in clinical dietetics acquired during the two-cycle (BA and MA) programs in dietetics at a medical university. We also argued that, in the view of the EFAD [36] directives stipulating that a boundary condition for acquiring the professional status of Registered Dietitian is to complete the education program leading to the Bachelor Degree (first cycle program), delivered at a higher education institution, which carries a minimum of 210 ECTS [36], Polish guidelines regarding the obtainment of the professional title "dietician" should recommend completion of the MA degree (second-cycle) program in dietetics because in the Polish reality the student of the first-cycle (BA) degree program acquires 180 ECTS (at the Medical University of Lublin with 3000 hours of classes), thereby failing to meet the EFAD requirements. Observe that EFAD's official position on the educational level of dietitians working in the clinical context states that "In health care, practice is restricted to dietitians who have undergone a recognized education and training" [1]. It is therefore justifiable to start discussion on the requirements for education and training in the dietitian's profession in order to optimize the professional preparation of specialists in dietetics. Despite the lack of legal regulations on the profession of dietitian in Poland, young people continue to be interested in studying dietetics (5-6 applicants for 1 place) [37]. In Poland, dietitians are currently educated at 52 universities and colleges, but the profile of these institutions training dietitians is highly diversified (agricultural, medical as well as social science colleges and universities) [38].

\section{CONCLUSIONS}

The finalization of measures intended to regulate the profession of dietitian in Poland would enhance the level of dietary services through elimination from the market persons without appropriate qualifications to practice the profession of dietitian, and would also contribute to optimizing the use of the therapeutic potential of the medical system in Poland and to optimization of measures within the public sector, especially in the field of health literacy. In reference to Don Nutbeam's classical model of health literacy, which distinguishes functional, interactive and critical health literacy [39], it should be emphasized that the elements of the dietitian's professional activities from the angle of health promotion refer to each of the distinguished aspects of health literacy [40].

\section{REFERENCES}

1. European dietitians and the discipline of dietetics. Statement by the European Federation of the Associations of Dietitians (EFAD), Consultation document. The Voice of European Dietitians, 2015.

2. Skrzypek M, Goral K. Dietetyk jako zawód medyczny w świetle dokumentów międzynarodowych oraz polskich regulacji prawnych. Hygeia Public Health. 2018;53(1):62-9.

3. efad.org [Internet] European Federation of the Associations of Dietitians; [cited 2018 Jul 23]. Available from: http://www.efad.org/en-us/about-efad/ definition-of-a-dietitian/.

4. Rozporządzenie Ministra Zdrowia z dnia 20.07.2011 r. w sprawie kwalifikacji wymaganych od pracowników na poszczególnych rodzajach stanowisk pracy w podmiotach leczniczych niebędących przedsiębiorcami (Dz. U. 2011 r., nr 151 poz. 896).

5. Rozporządzenie Ministra Zdrowia z 19.12.2014 r. zmieniające rozporządzenie w sprawie świadczeń gwarantowanych z zakresu lecznictwa uzdrowiskowego (Dz.U. 2014, poz. 1963). 
6. csioz.gov.pl [Interenet] Centrum Systemów Informacyjnych Ochrony Zdrowia, Warszawa; [cited 2018 Jul 10]. Available from: https:/www.csioz. gov.pl/fileadmin/user upload/statystyka/biuletyn 2017 5a2e86b48fba0. pdf .

7. csioz.gov.pl [Interenet] Centrum Systemów Informacyjnych Ochrony Zdrowia, Warszawa; [cited 2018 Jul 10]. Available from: https://csioz.gov. pl/aktualnosci/szczegoly/biuletyn-statystyczny-ministerstwa-zdrowia-narok-2016/

8. nik.gov.pl [Internet] Najwyższa Izba Kontroli, Warszawa. [cited 2018 Jul 23]. Available from: https://www.nik.gov.pl/plik/id,16459,vp,18989.pdf .

9. Jarosz M, editor. Normy żywienia dla populacji Polski. Wydawnictwo IŻŻ, Warszawa 2017 https://ncez.pl/upload/normy-net-1.pdf

10. Walczak M, Krasowska-Walczak G. Dietetyk na rynku usług medycznych w Polsce i wybranych krajach. Zdr Publ Zarządz. 2015;13(2):204-15.

11. ptd.org.pl [Internet] Polskie Towarzystwo Dietetyki, Warszawa; [cited 2018 Jul 23] Available from: http://ptd.org.pl/sites/default/files/kodeksetyki-zawodowej-dietetyka.pdf .

12. Rozporządzenie Ministra Zdrowia z dnia 8 lutego 2018 r. zmieniające rozporządzenie w sprawie szczegółowych kryteriów wyboru ofert w postępowaniu w sprawie zawarcia umów o udzielanie świadczeń opieki zdrowotnej (Dz.U. 2018, poz. 385).

13. Rozporządzenie Ministra Zdrowia $z$ dnia 22 listopada 2013 r. w sprawie świadczeń gwarantowanych z zakresu leczenia szpitalnego (Dz.U. 2013 poz. 1520).

14. Polskie Towarzystwo Diabetologiczne. Zalecenia kliniczne dotyczące postępowania u chorych na cukrzycę 2018. Diabetol Prakt. 2018;4(1):1102.

15. Rozporządzenie Ministra Zdrowia z dnia 15 września 2011 r. zmieniające rozporzadzenie w sprawie świadczeń gwarantowanych z zakresu leczenia szpitalnego (Dz. U. z 2011 r. Nr 202, poz. 1191).

16. Obwieszczenie Ministra Zdrowia z dnia 14 kwietnia 2016 r. w sprawie ogłoszenia jednolitego tekstu rozporządzenia Ministra Zdrowia w sprawie świadczeń gwarantowanych z zakresu leczenia szpitalnego (Dz. U. z 2016 r., poz. 694).

17. Pertkiewicz M, Korda T (ed). Standardy żywienia pozajelitowgo i dojelitowego. Warszawa: Wydawnictwo Lekarskie PZWL; 2005.

18. Polskie Towarzystwo Żywienia Pozajelitowego, Dojelitowego i Metabolizmu. Standardy żywienia pozajelitowego i dojelitowego. Kraków: Krakowskie Wydawnictwo Naukowe Scientifica; 2013.

19. Obwieszczenie MZ z 30 stycznia 2018 r w sprawie ogłoszenia jednolitego tekstu rozporządzenia MZ w sprawie świadczeń gwarantowanych zakresie rehabilitacji leczniczej (Dz. U. 2018, poz. 465).

20. Ustawa z dnia 2 lipca 2004 r. o swobodzie działalności gospodarczej, (Dz.U. 2004 nr 173 poz. 1807).

21. Ustawa z dnia 19 listopada 1999 r. Prawo działalności gospodarczej. (Dz.U. 1999 nr 101 poz. 1178)

22. Całyniuk B. Miejsce pracy dietetyka we współczesnej ochronie zdrowia. Piel Zdr Publ. 2014:4(3):285-92.

23. Goral K, Siwiela-Tomaszczyk J, Krzyszycha R, Skrzypek M. Controversial alternative diets in the light of current dietary recommendations for treatment of overweight and obesity. Pol J Public Health. 2017;127(2):925

24. Ustawa z dnia 27 października 2017r. o podstawowej opiece zdrowotnej (Dz.U. 2017 poz. 2217).

25. ptd.org.pl [Internet] Polskie Towarzystwo Dietetyki, Warszawa; [cited 2018 Jul 23] Available from: https://ptd.org.pl/artykuly/nareszcie-miejscedla-dietetyka-w-ochronie-zdrowia-strategia-zmian-w-systemie-ochrony .

26. Rozporzązenie Ministra Zdrowia z dnia 28 września 2016 w sprawie zakresu zadań lekarza podstawowej opieki zdrowotnej, pielęgniarki podstawowej opieki zdrowotnej i położnej podstawowej opieki zdrowotnej (Dz. U. z 2016 r., poz. 1567).

27. bda.uk.com [Internet] British Dietetic Association, Birmingham; [cited 2018 Jul 20] Available from: https://www.bda.uk.com/improvinghealth/ healthprofessionals/cost benefit of dietitians

28. Directive 2005/36/EC of the European Parliament and of the Council of 7 September 2005 on the recognition of professional qualifications, article 3, point 1(a). Official Journal of the European Union; L 255/22 30.9.2005.

29. http://www.sejm.gov.pl/ [Internet] Sejm Rzeczypospolitej Polskiej, Projekt ustawy o niektórych zawodach medycznych; [cited 2018 Jul 19]. Available from: http://orka.sejm.gov.pl/proc5.nsf/projekty/1553_p.htm .

30. nauka.gov.pl [Internet] Ministerstwo Nauki i Szkolnictwa Wyższego; [cited 2018 Jul 19]. Available from: https://www.nauka.gov.pl/ogolneinformacje-o-systemie-uznawania-kwalifikacji-zawodowych-zgodnie-zdyrektywa-2005-36-we/co-to-jest-zawod-regulowany-dzialalnosc-regulowana.html .
31. Rozporządzenie Ministra Edukacji Narodowej i Sportu z dnia 8 maja 2004 r. w sprawie klasyfikacji zawodów szkolnictwa zawodowego (Dz. U. z 2004 r. Nr 114, poz. 1195)

32. Ustawa z dnia 15 kwietnia 2011 r. o działalności leczniczej (Dz. U. z 2011 r. Nr 112, poz. 654).

33. efad.org [Internet] European Federation of the Associations of Dietitians; [cited $2018 \mathrm{Jul} 23$ ]. Available from: http://www.efad.org/media/1183/mission_and_vision_paper.pdf .

34. Ustawa z dnia 22 grudnia 2015 r. o zasadach uznawania kwalifikacji zawodowych nabytych w państwach członkowskich Unii Europejskiej (Dz. U. 2015, poz. 65).

35. ptd.org.pl [Internet] Polskie Towarzystwo Dietetyki, Warszawa; [cited $2018 \mathrm{Jul} 23$ ] Available from: https://ptd.org.pl/ksztalcenie

36. efad.org [Internet] European Federation of the Associations of Dietitians; [cited 2018 Jul 23]. Available from: http://www.efad.org/media/1442/ efad_benchmarkjune2005_uk.pdf.

37. Jelonek M. Studenci - przyszłe kadry polskiej gospodarki. Raport z badań studentów i analizy kierunków kształcenia realizowanych w 2010 r. w ramach projektu „Bilans Kapitału Ludzkiego”. 1 st ed. Polska Agencja Rozwoju Przedsiębiorczości, Warszawa, 2011.

38. wybierzstudia.nauka.gov.pl [Internet] Ministerstwo Nauki i Szkolnictwa Wyższego, Ośrodek Przetwarzania Informacji Państwowy Instytut Badawczy, Warszawa; [cited 2018 Jul 23] Available from: http:/wybierzstudia.nauka.gov.pl/pages/search/index

39. Don Nutbeam. Health literacy as a public health goal: a challenge for contemporary health education and communication strategies into the $21 \mathrm{st}$ century. Health Promotion Int. 2000;15(3):259-67.

40. Wood J, Gillis DE. Exploring dietitians' engagement with health literacy: concept and practice. Can J Diet Pract Res. 2015;76(2):51-5.

\section{Corresponding author}

Dr hab. Michał Skrzypek

Department of Clinical Dietetics

Faculty of Health Sciences

Medical University of Lublin

1 Chodźki St., 20-093 Lublin, Poland

E-mail: michal.skrzypek@umlub.pl

tel: +48814486900 